\title{
Notas sobre complementação recursal no entrelaçar de Embargos de Divergência e cabimento de recurso extraordinário contra acórdão do Superior Tribunal de Justiça
}

Notes about the appeal complementation in the relation between the embargos de divergência and the recurso extraordinário against decisions of the Superior Tribunal de Justiça.

Ravi Peixoto'

'Universidade do Estado do Rio de Janeiro - UFRJ, Brasil

\section{Resumo}

Esse texto objetiva propor uma solução para uma lacuna existente na situação em que, sendo cabíveis embargos de divergência e recurso extraordinário, o primeiro é provido ou altera a fundamentação do julgado, mesmo sendo desprovido. A proposta é a de aplicação, por analogia, da regulação dos embargos de declaração, que permite, em situação semelhante, a alteração ou complementação do outro recurso utilizado contra a decisão embargada, com as suas devidas adaptações. Palavras-chave: Embargos de divergência. Analogia. Complementação recursal. Embargos de declaração.

\begin{abstract}
This text aims to propose a solution to a gap in the situation where it is possible to use the embargos de divergência and the recurso extraordinário against the same decision, and the first appeal changes the decision. The proposal is to use the analogy to allow the application of the regulation in the embargos de declaração that allows, in a similar situation, the changing of the other appeal used against the decision, with its due adaptations.
\end{abstract}

Keywords: Embargos de divergência. Analogy. appeal complementation. Embargos de declaração.

\section{Introdução}

Os embargos de divergência são uma espécie recursal (art. 994, IX, CPC), cujo objetivo é o de uniformizar a jurisprudência dos tribunais superiores, podendo ser utilizado no Superior Tribunal de Justiça e no Supremo Tribunal Federal. Significa que há nítida conexão entre o cabimento desse recurso e o dever de uniformização constante do art. 926 do CPC, evitando divergências dentro dos próprios tribunais superiores, o que é um dever mínimo para a construção de um sistema de precedentes.

Por mais que os tribunais superiores tenham, dentre suas funções, a de formar precedentes, a divisão em diversos órgãos fracionários, como é o caso do STJ, que é composto por seis turmas e três sessões e o STF, que possui duas turmas, acaba permitindo que haja divergência dentro do próprio tribunal. Por óbvio, não se deve admitir a manutenção de tal dispersão de entendimento, sendo uma das formas de evitá-la a utilização dos embargos de divergência, sendo ainda possível vislumbrar, também com esse objetivo, o incidente de assunção de competência (art. 947, CPC), com caráter mais preventivo. 
Dentro da lógica dos precedentes, os embargos de divergência possuem a função de oportunizar o debate entre teses divergentes dentro de um mesmo tribunal, de forma que uma delas, ou mesmo uma terceira, possa vir a prevalecer. ${ }^{1}$ Com essa uniformização do entendimento, a Corte passa a ter aptidão de orientar a sociedade e guiar os órgãos fracionários, os tribunais inferiores e os juízes de primeiro grau. ${ }^{2}$

Quanto ao cabimento e o procedimento, o CPC/2015 realizou diversas modificações e, da versão originária da legislação, já foram feitas diversas mudanças por meio da Lei n. 13.256/2016, com o nítido objetivo de diminuir a quantidade de processos dos tribunais superiores. De toda forma, uma das alterações realizadas no procedimento dos embargos de divergência foi mantida, que é, no caso do desprovimento ou não alteração do julgamento anterior no STJ, a desnecessidade de ratificação do recurso extraordinário interposto pela outra parte antes da publicação do julgamento dos embargos de divergência (art. 1.044, CPC). Ocorre que a regulação dessa temática no CPC foi tão singela, que acabou sendo omissa para algumas situações, pois sequer trata do que deve ser feito nas situações em que os embargos de divergência alterarem a conclusão ou a própria motivação do acórdão recorrido. $\mathrm{O}$ objetivo desse texto é o de analisar essa temática, verificando as possíveis soluções constantes do próprio CPC.

\section{Noções acerca do cabimento dos embargos de divergência}

Os embargos de divergência apenas podem ser interpostos contra acórdãos de órgãos fracionários (art. 1.043, caput), independentemente de a decisão ser por maioria de votos ou por unanimidade, eis que basta haver a divergência entre teses. Um destaque óbvio é o de que não se admite a utilização dessa espécie recursal em face de decisões monocráticas. ${ }^{3}$ Caso o acórdão advenha da Corte Especial do STJ ou do Pleno do STF, naturalmente, essa espécie recursal não estará disponível à parte, por não se tratar de órgão fracionário e pela lógica de que esse entendimento é o que deve prevalecer no tribunal. No entanto, é possível cogitar que o acórdão paradigma possa ser da Corte Especial ou do Plenário, eis que a limitação se dirige tão somente ao acórdão embargado. ${ }^{5}$

Requer-se ainda que o acórdão paradigma invocado seja do próprio tribunal, não sendo possível sua utilização para suprir divergências externas, que seria o contraste entre julgados exógenos ${ }^{6}$ e, em geral de "outro órgão" (art. 1.043, I e III, CPC), que pode significar turma, seção ou mesmo do plenário/corte especial. No entanto, a própria legislação permite o eventual cabimento para dirimir a divergência dentro de uma mesma turma, quando a sua composição tenha sofrido alteração de mais da metade dos

1 Admitindo a possibilidade de desenvolvimento de uma nova tese no julgamento dos embargos de divergência: SOUZA, Bernardo Pimentel. Introdução aos recursos cíveis e à ação rescisória. 10ạ ed. São Paulo: Saraiva, 2014, p. 595. Na jurisprudência, há decisão do STJ afirmando exatamente que "Conhecidos os embargos de divergência, a decisão a ser adotada não se restringe às teses suscitadas nos arestos em confronto recorrido e paradigma, sendo possível aplicar-se uma terceira tese, pois cabe a Seção ou Corte aplicar o direito à espécie”. (STJ, Corte Especial, EREsp 513.608/RS, Rel. Min. João Otávio De Noronha, j. 05/11/2008, DJe 27/11/2008). No mesmo sentido: STJ, 1ª Seção, EREsp 811.712/SP, Rel. Min. Hamilton Carvalhido, Rel. p/ Acórdão Min. Castro Meira, j. 12/12/2012, DJe 06/03/2013. Essa interpretação parece ser ainda mais simples no CPC/2015, devido ao disposto no caput do art. 1.034: "Admitido o recurso extraordinário ou o recurso especial, o Supremo Tribunal Federal ou o Superior Tribunal de Justiça julgará o processo, aplicando o direito".

2 MARINONI, Luiz Guilherme. O STJ enquanto Corte de precedentes. 2a ed. São Paulo: RT, 2014, p. 214.

3 No mesmo sentido: CUNHA, Leonardo Carneiro da; DIDIER JR., Fredie. Curso de direito processual civil... cit., p. 388. Também da mesma forma, sob a égide do CPC/1973, em raciocínio aplicável ao CPC/2015: FREIRE, Rodrigo da Cunha Lima. Embargos de divergência em recurso especial e em recurso extraordinário. No prelo. Em sentido contrário, ainda sob a égide do CPC/1973, mas em raciocínio, que, em tese, poderia ser sustentado à luz do CPC/2015: PEREIRA, Milton Luiz. Embargos de divergência contra decisão lavrada por relator. Revista dos Tribunais. São Paulo: RT, v. 778, ago.-2000.

4 RODRIGUES, Luiza Silva. Embargos de divergência: o cumprimento da função precípua dos tribunais superiores. Dissertação de Mestrado. Santa Catarina: UFSC, 2017, p. 388-389.

$5 \quad$ No mesmo sentido: RODRIGUES, Luiza Silva. Embargos de divergência... cit., p. 390.

6 A nomenclatura de divergência interna e externa advém da seguinte obra: MANCUSO, Rodolfo Camargo de. Divergência jurisprudencial e súmula vinculante. $4^{\underline{a}}$ ed. São Paulo: RT, 2010, p. 293, 300. 
seus membros (art. 1.043, §3oㅡ, CPC). A divergência também deve ser atual e é com essa lógica que deve ser tido como correto o enunciado n. 168 do STJ, segundo o qual "Não cabem embargos de divergência, quando a jurisprudência do tribunal se firmou no mesmo sentido do acórdão embargado”. Com essa mesma lógica, tem-se ainda o enunciado n. $247^{8}$ da jurisprudência dominante do STF.

O acórdão paradigma tem uma abertura mais ampla de utilização do que do acórdão recorrido, pois aquele pode tanto advir do julgamento de recursos extraordinários (recurso especial ou extraordinário), como de recursos com amplo efeito devolutivo (como no recurso ordinário) e de ações de competência originária (como é o caso do mandado de segurança), nos termos do art. 1.043, §1º, CPC.

Além disso, apenas serão cabíveis no julgamento de recursos extraordinários e especiais (art. 1.043, I e II, CPC). A despeito da redação do CPC/2015, parece ser possível admitir o cabimento de tal recurso em face de acórdão que, em agravo interno ou em agravo em recurso especial ou extraordinário, decide o respectivo recurso especial ou extraordinário, entendimento manifestado pelo enunciado n. 230 do FPPC. ${ }^{9}$ A lógica, nesse caso, é a de que é por meio do agravo interno (que substituiu o agravo regimental) e do agravo em recurso especial ou extraordinário que o colegiado analisa o respectivo recurso especial ou extraordinário e, na verdade, é por meio desses agravos que está sendo decidido o especial ou o extraordinário. Portanto, os embargos de divergência, em tal situação, estão sendo interpostos em face do julgamento do recurso especial e do extraordinário, a diferença é que os agravos é que permitiram o conhecimento, pelo colegiado, dos recursos excepcionais. Esse posicionamento, de certa forma, já era utilizado pelo STJ, por meio do enunciado n. 316 de sua jurisprudência dominante..$^{10}$

Acerca da matéria que pode ser alvo de divergência, esta pode ter natureza tanto de direito material, como de direito processual. Conexo a esse tema, faz-se referência ao fato de que o acórdão há de ter julgado o mérito (art. 1.043, I, CPC), que deve ser entendido como mérito do recurso e não da causa, que pode estar limitado a discutir matéria processual, como a competência.

É possível ainda a sua utilização nos casos em que a o acórdão paradigma não tenha conhecido do recurso, embora tenha apreciado a controvérsia (art. 1.043, III, CPC), ${ }^{11}$ um problema que costuma gerar confusões no âmbito da delimitação da competência da ação rescisória e a verificação da (in) competência do tribunal superior. Exemplo claro disso foi a edição da súmula n. 249 do STF, segundo a qual "É competente o Supremo Tribunal Federal para a ação rescisória, quando, embora não tendo conhecido do recurso extraordinário, ou havendo negado provimento ao agravo, tiver apreciado a questão federal controvertida”. ${ }^{2}$ Esse problema ocorria devido a um desvio de técnica dos tribunais superiores, que ocorre no âmbito do STF desde antes da CF/1988 e que foi incorporado pelo STJ, que apenas vislumbravam duas hipóteses: a) ou verificavam que havia efetivamente contrariedade ao texto normativo apontado como violado ou b) não conheciam o recurso.

Esse desvio da técnica foi destacado por Barbosa Moreira, apontando que era incompreensível que ao tribunal apenas fosse possível vislumbrar apenas duas alternativas: o provimento ou o não conhecimento

7 CUNHA, Leonardo Carneiro da; DIDIER JR., Fredie. Curso de direito processual civil... cit., p. 390; ASSIS, Araken de. Manual dos recursos. 7ª ed. São Paulo: RT, 2015, p. 907; MACEDO, Lucas Buril de. Precedentes judiciais e o direito processual civil. 2a ed. Salvador: Juspodivm, 2017, p. 519.

8 S. 353: São incabíveis os embargos da Lei 623, de 19.02.49, com fundamento em divergência entre decisões da mesma turma do Supremo Tribunal Federal.

$9 \quad$ Na doutrina, nesse sentido: OLIVEIRA, Pedro Miranda. Novíssimo sistema recursal conforme o CPC/2015. $3^{-\mathbf{a}}$ ed. Florianópolis: Empório do Direito, 2017, p. 336.

10 S. 316: Cabem embargos de divergência contra acórdão que, em agravo regimental, decide recurso especial.

11 Há quem diga que passou-se a permitir que a divergência não viesse a ocorrer necessariamente no mesmo nível de cognição. (Alvim, Teresa Arruda Alvim. Comentários ao art. 1.043. STRECK, Lênio Luiz; NUNES, Dierle; CUNHA, Leonardo Carneiro; FREIRE, Alexandre (Coords.). Comentários ao Código de Processo Civil. São Paulo: Saraiva, 2016, p. 1.395; ALVIM, Teresa Arruda; DANTAS, Bruno. Recurso especial, recurso extraordinário e a nova função dos tribunais superiores no direito brasileiro. $3^{\mathrm{a}}$ ed. São Paulo: RT, 2016, p. 570). No mesmo sentido: RODRIGUES, Luiza Silva. Embargos de divergência: o cumprimento da função precípua dos tribunais superiores. Dissertação de Mestrado. Santa Catarina: UFSC, 2017 , p. 351.

12 Sobre a temática no âmbito da rescisória, remetemos o leitor a um outro texto: SILVEIRA, Marcelo Pichioli da PEIXOTO, Ravi. Ação Rescisória e competência: novos e velhos problemas. Revista Brasileira de Direito Processual - RBDPro, Belo Horizonte: Fórum, n. 96, out./dez.-2016, p. 220-224. 
do recurso. ${ }^{13}$ Isso porque "A opção não pode ser entre conhecer e negar provimento, mas entre conhecer e não conhecer, preliminarmente, e entre dar e negar provimento, no mérito". ${ }^{14}$ A lógica impunha que, preliminarmente, fosse feito o juízo de admissibilidade, que consiste no conhecimento ou não do recurso (a alegação da contrariedade), para, depois, no caso de conhecer do recurso, provê-lo ou não. Afinal, "não fazia sentido (...) que o tribunal declarasse não conhecer do recurso depois de haver examinado toda a matéria discutida pelo recorrente, para negar-lhe razão: que sobraria para o juízo de mérito?"15

Destaque-se que essa admissão de utilização de um acórdão paradigma que parou no juízo de admissibilidade apenas é admitido nas hipóteses em que se tem um "falso" juízo de admissibilidade que acaba por entrar no mérito.

Não se admite embargos de divergência em relação a recursos que não ultrapassaram o juízo de admissibilidade (seja do ponto de vista do acórdão recorrido, seja do ponto do acórdão paradigma), possibilidade que fora inserida na versão originária, mas revogada pela Lei 13.256/2016. ${ }^{16}$ Seria possível imaginar o cabimento quando ambos os recursos ultrapassassem o juízo de admissibilidade, mas houvesse divergência quanto a alguma questão processual atinente a esse juízo. No entanto, parece bastante difícil imaginar uma divergência nessa situação, pois necessariamente os requisitos processuais teriam sido ultrapassados e a conclusão não teria como ser divergente. Talvez houvesse a possibilidade no caso de um recurso apenas ter ultrapassado a admissibilidade de um dos capítulos recorridos e divergir de outro em que todo o recurso foi admitido. De toda forma, não parece possível admitir que o acórdão recorrido e nem o paradigma sejam um julgamento que não ultrapassou o juízo "verdadeiro" de admissibilidade, eis que tal possibilidade não é admitida em nenhuma das hipóteses do art. 1043 do CPC. ${ }^{17}$

De forma resumida, os requisitos para o cabimento de tal espécie recursal são: a) divergência atual em relação acórdão de outro órgão do mesmo tribunal, ou do mesmo órgão com alteração de mais de metade dos membros; b) julgamento colegiado de recurso especial ou extraordinário ou de acórdão que, em agravo interno ou em agravo em recurso especial ou extraordinário, decide o respectivo recurso especial ou extraordinário; c) de mérito ou que, embora não tenha conhecido do recurso, tenha apreciado a controvérsia.

Requer-se ainda que o recorrente comprove essa divergência seja por meio de certidão, cópia ou mesmo citação de repositório de jurisprudência, mesmo em mídia eletrônica, onde tiver sido publicado o acórdão divergente e ainda por meio da reprodução de julgado disponível na rede mundial de computadores por meio da indicação da respectiva fonte (art. 1.043, §4º, CPC). A divergência deve ser demonstrada de forma analítica, comparando-se os dois acórdãos, identificando as semelhanças entre as decisões e o seu posicionamento diverso (art. 1.043, $§ 4^{\circ}, \mathrm{CPC}$ ), mesmo nos casos de divergência notória. ${ }^{18}$

\section{A possibilidade de interposição de recurso extraordinário e os embargos de divergência no STJ}

13 MOREIRA, José Carlos Barbosa. Efetividade e técnica do processo. BARBOSA MOREIRA, José Carlos (coord). Revista Forense - comemorativa 100 anos. Rio de Janeiro: Forense, 2006, t. V, p. 586-587, destaques no original.

14 MOREIRA, José Carlos Barbosa. O juízo de admissibilidade no sistema dos recursos civis. Revista de Direito da Procuradoria Geral do Rio de Janeiro. Rio de Janeiro, v. 17, 1976, p. 105.

15 MOREIRA, José Carlos Barbosa. Questões de técnica de julgamentos nos tribunais. Temas de direito processual: nona série. São Paulo: Saraiva, 2007, p. 290.

16 Há quem ainda admita tal possibilidade a despeito da alteração normativa, afirmando que "pode-se sustentar, à luz do $§ 2^{\circ}$ do mesmo art. 1.042 (que não foi revogado), que essa hipótese ainda está abrangida pelos embargos de divergência: esse dispositivo autoriza o uso dos embargos de divergência quando a divergência está ou no plano do direito material ou no âmbito do direito processual". (ALVIM, Teresa Arruda; DANTAS, Bruno. Recurso especial, recurso extraordinário e a nova função dos tribunais superiores no direito brasileiro... cit., p. 570).

17 Fazendo menção à impossibilidade de utilização, como acórdão embargado, de decisão que não ultrapassa o juízo de admissibilidade (STJ, Corte Especial, AgInt nos EAREsp 678.028 / BA, Rel. Min. Mauro Campbell Marques, j. 15/03/2017, DJe 21/03/2017).

18 STJ, Corte Especial, EDcl no AgRg nos EAg 1.354.512/SP, Rel. Min. Raul Araújo, j. 05/10/2016, DJe 21/10/2016. No mesmo sentido: STJ, Corte Especial, AgInt nos EAREsp 261.239/MT, Rel. Min. Humberto Martins, j. 17 /08 /2016, DJe de $30 / 08 / 2016$. 
É possível que a decisão do tribunal esteja baseada em fundamento constitucional e, em tal hipótese, ainda será admissível, em tese, recurso extraordinário. Um resumo dos casos em que poderia haver esse interesse foi realizado por Fredie Didier Jr. e Leonardo Carneiro da Cunha:

a) o STJ deixa de aplicar, por entender inconstitucional, a lei sobre cuja interpretação se discute; b) ou julgar sem a observância dos requisitos formais exigidos para o cabimento do recurso especial; c) ou dar interpretação nova que a parte entende ser inconstitucional (STF, 1ํㅜ.. , AG n. 141.518-DF-AgRg, rel. Min. Moreira Alves, publicado no DJ de 11.03.1994, p. 4.113); d) STJ deixa de aplicar a lei, sem reputá-la inconstitucional, não observando o comando do art. 97 da Constituição Federal, nem o enunciado 10 da súmula vinculante do STF. ${ }^{19}$

Percebe-se que a atuação do STJ na interpretação das normas constitucionais é bastante ampla, em especial, no caso da interpretação à luz da Constituição da legislação infraconstitucional, na ideia de constitucionalização do direito infraconstitucional. Um caso paradigmático de tal situação foi no julgamento de um recurso especial que versava sobre o direito ao esquecimento, em que o próprio ministro relator Luis Felipe Salomão realizou grande digressão sobre a filtragem constitucional a ser feita pelo STJ. ${ }^{20}$

Destaque-se ainda a grande liberdade do STJ no controle de constitucionalidade nas ações de competência originária e nos recursos ordinários, ${ }^{21} \mathrm{em}$ que sequer há a discussão do problema do prequestionamento ou da preclusão da impugnação do fundamento constitucional no tribunal a quo. E, por mais que, de tais acórdãos não sejam cabíveis os embargos de divergência, eles podem ser utilizados como acórdãos paradigmas, o que amplia eventual possibilidade de divergência.

Essa breve digressão acerca do exercício da jurisdição constitucional pelo STJ tem o simples objetivo de demonstrar algo que parece não ser muito mencionado pela doutrina: a possibilidade de a divergência apta a gerar o cabimento dos embargos de divergência, no STJ, pode ter natureza constitucional. E tal situação não deve ser tida como absurda.

Por mais que não caiba ao STJ a competência constitucional para fixar a interpretação da constituição para os demais tribunais, para além da própria utilidade de dirimir eventual divergência dentro do próprio tribunal, pode ser, por exemplo, um daqueles casos em que o STF destaca ser caso de violação reflexa. ${ }^{22}$ Isso sem falar das situações em que o STF não reconheça a repercussão geral e reste ao STJ interpretar uma determinada matéria e não se pode vetar a tal tribunal de usar a Constituição como parâmetro, sob pena de se ter uma interpretação do direito "em tiras". ${ }^{23}$

19 CUNHA, Leonardo Carneiro da; DIDIER JR., Fredie. Curso de direito processual civil... cit., p. 351.

20 STJ, 4⿳一巛工 ${ }^{-}$T., REsp 1.335.153/RJ, Rel. Min. Luis Felipe Salomão, j. 28/05/2013, DJe 10/09/2013.

21 Destacando essa situação: ZAVASCKI, Teori Albino. Jurisdição constitucional do Superior Tribunal de Justiça. Revista de Processo. São Paulo: RT, n. 212, set.-2012, versão eletrônica, tópicos 2 e 3.

22 Afinal, na ofensa reflexa, não se pode ignorar a atuação da norma constitucional na interpretação da legislação infraconstitucional tida por violada. Em caso analisado pelo STF e em que foi reconhecida a inconstitucionalidade reflexa, houve reconhecimento de ofício da incompetência no caso de violação do art. 578, V, do CPC/1973, segundo o qual, a execução fiscal será proposta no foro do domicílio do réu, eis que se trataria de competência funcional e absoluta e não meramente territorial. O recorrente alegou que haveria ofensa ao art. 109, §3º, da CFRB, pois a delegação da jurisdição federal para a justiça estadual deve ser interpretada de forma restrita, eis que trata de verdadeira exceção à regra geral de competência da justiça federal e que somente a primeira parte do texto constitucional teria natureza de competência. Assim, o caso das execuções fiscais seria uma competência territorial, de natureza relativa e que não poderia ser conhecida de ofício. Afirmou o STF que o questionamento seria apenas da legitimidade ou não do conhecimento de ofício da incompetência, que seria matéria infraconstitucional (STF, ARE 840.432 RG, Rel. Min. Teori Zavascki, j. 20/11/2014, DJe 11/12/2014). No entanto, a interpretação do texto constitucional seria relevante, eis que, se houvesse interpretação de que o mencionado texto normativo encerra hipótese de competência relativa, a conclusão sobre o reconhecimento da incompetência de ofício seria alterado.

23 Eros Grau sempre afirmou que "não se interpreta o direito em tiras, aos pedaços”, critica que poderia ser dirigida ao STJ, caso houvesse absoluta vedação à utilização do Constituição como parâmetro interpretativo (GRAU, Eros Roberto. Por que tenho medo dos juízes (a interpretação/aplicação do direito e os princípios). São Paulo: Malheiros, 2014, p .84. Igualmente em: GRAU, Eros Roberto. O direito posto e o direito pressuposto. $7^{\underline{a}}$ ed. São Paulo: Malheiros, 2008, p. 68. 
Em outros termos, a divergência que permite o cabimento dos embargos de divergência pode tanto ter natureza constitucional como infraconstitucional. E, do capítulo relativo ao direito constitucional, será ainda cabível o recurso extraordinário.

Ocorrendo tal situação, compete ao recorrente, inicialmente, interpor os embargos de divergência e, após o seu julgamento, interpor o recurso extraordinário. Destaque-se não haver obrigatoriedade da prévia interposição dos embargos de divergência para que a parte possa utilizar-se do recurso extraordinário. Assim, tem-se "uma clara exceção ao requisito de admissibilidade do esgotamento das vias recursais pelo caráter subjetivo e facultativo dos embargos de divergência”. ${ }^{24} 25$

Como forma de evitar que a parte viesse a interpor, de imediato, tais recursos, por receio de problemas atinentes à tempestividade ou da eventual obrigatoriedade prévia de interposição simultânea, o que, na verdade, seria um erro, pois impediria o conhecimento do recurso interposto por último, em face do princípio da unirrecorribilidade e também em consequência da preclusão consumativa ${ }^{26}$ foi previsto, de forma expressa, a interrupção do prazo para a interposição do recurso extraordinário a ser interposto por qualquer uma das partes (art. 1.044, §1º, CPC). Portanto, a parte pode, sem qualquer receio, interpor os embargos de divergência, esperar o seu julgamento e, só então, utilizar-se do recurso extraordinário, se ainda cabível.

Destaque-se que a tendência deve ser a de produção do efeito interruptivo, mesmo que não ultrapassado o juízo de admissibilidade, somente não interrompendo o prazo para outros recursos quando intempestivos ou manifestamente incabíveis, por exemplo, em hipótese em que sequer se alega a existência de divergência jurisprudencial. Esse raciocínio é utilizado pelo STJ no caso dos embargos de declaração e tende a ser mantido agora para os embargos de divergência. ${ }^{27}$

Além disso, é possível ainda que contra um mesmo acórdão do STJ seja cabível por uma parte o recurso extraordinário e, pela outra, os embargos de divergência. Ou seja, que venha a ocorrer a sucumbência recíproca. Pode ocorrer a seguinte situação: a parte que apenas tenha interesse na interposição do recurso extraordinário venha a fazê-lo antes que a outra parte interponha os embargos de divergência.

Imagine-se ainda outra hipótese: A e B são litisconsortes e um determinado capítulo com matéria constitucional gera interesse para ambos em interpor recurso extraordinário e embargos de divergência. Ocorre que A se adianta e interpõe o recurso extraordinário no terceiro dia, eis que não há obrigatoriedade da prévia interposição dos embargos de divergência; mas B o faz e esse seu recurso pode alterar a decisão e o cabimento do recurso extraordinário de A.

Em ambos os exemplos, o recurso extraordinário já interposto fica sujeito ao julgamento dos embargos de divergência, que pode trazer diversos reflexos quando ao cabimento e a fundamentação do extraordinário.

Caso a parte que poderia interpor o recurso extraordinário o faça antes de a outra interpor os embargos de divergência, podem ocorrer duas situações: a) desprovimento sem alteração na fundamentação; b) desprovimento com alteração na fundamentação e c) provido, em que haverá alteração da fundamentação e do dispositivo.

O CPC/2015, em relação aos embargos de divergência contempla tão somente a situação $b$, prevendo que, em tal hipótese, o recurso extraordinário será processado e julgado independentemente de

24 LEMOS, Vinicius. Recursos e processos nos tribunais no novo CPC. 2ª ed. São Paulo: Lexia, 2016, p. 287.

25 Reconhecendo o caráter facultativo dos embargos de divergência: STF, 1aㅡ., RE 524.385 AgR, Rel. Min. Dias Toffoli, j. $07 / 08 / 2012$, DJe-167 24/08/2012.

26 STJ, 1ª Seção, AgInt nos EREsp 1.068.165/MG, Rel. Min. Og Fernandes, j. 22/02/2017, DJe 2/03/2017. Na doutrina com a mesma conclusão, embora tratando de hipótese de interposição conjunta de embargos de declaração e outro recurso, com raciocínio que também serve a esse exemplo: JORGE, Flávio Cheim. Teoria geral dos recursos cíveis. $7^{a}$ ed. São Paulo: RT, 2015 , p. 181.

27 "deve-se firmar o entendimento de que os embargos de declaração somente não interrompem o prazo para outros recursos quando intempestivos, manifestamente incabíveis ou nos casos em que oferecidos, com pedido de aplicação de efeitos infringentes, sem a indicação, na peça de interposição, de vício próprio de embargabilidade (omissão, contradição, obscuridade ou erro material)". (STJ, Corte Especial, EAREsp 175.648/RS, Rel. Min. Og Fernandes, j. 24/10/2016, DJe $04 / 11 / 2016)$. 
confirmação pela outra parte (art. 1.044, \$2º). Não há qualquer menção a eventual possibilidade de aditamento ao recurso. Tal situação é prevista tão somente para os embargos de declaração, tema sobre o qual será feita breve análise para ser possível analisar o caso dos embargos divergentes.

\section{O aditamento no caso dos embargos de declaração}

O recurso de embargos de declaração pode ser oposto contra qualquer decisão e, de acordo com o caput do art. 1.026, interrompem o prazo para a interposição dos demais recursos.

Ocorre que, na grande maioria dos casos, a decisão em relação a qual são cabíveis o recurso de embargos de declaração também poderia ser alvo de outros recursos. Por exemplo, em relação à sentença, o recurso adequado para questioná-la é a apelação e, de um acórdão, na grande maioria dos casos, os recursos cabíveis serão o recurso especial e o extraordinário.

Em face dessa situação, pode ocorrer o seguinte: antes que uma das partes oponha os embargos de declaração, a outra já interpôs o recurso apto a discutir o mérito da decisão. No entanto, opostos os embargos de declaração o prazo para a oposição de outras espécies recursais pelas partes estará interrompido.

O CPC/2015 altera essa lógica caso uma das partes já tenha interposto recurso antes que a outra tenha oposto os embargos de declaração. De acordo com os $\${4^{\circ}}^{\mathrm{o}}$ e $5^{\mathrm{o}}$, do art. 1.024, podem ocorrer duas situações caso essa situação ocorra:

a) Se os embargos de declaração forem acolhidos de forma a modificar a decisão embargada, o embargado terá o direito de complementar ou alterar suas razões recursais, nos exatos limites da modificação, no prazo de 15 dias da publicação da decisão que julgou os embargos $\left(\S^{\circ}{ }^{\circ}\right)$.

b) Se os embargos forem rejeitados ou acolhidos sem alterar as conclusões do julgamento anterior, o recurso interposto pelo embargado deverá ser processado e julgado independente de ratificação $\left(5^{\circ} 5^{\circ}\right)$.

Em relação ao ponto "b", é preciso destacar que o CPC/2015 adotou o entendimento do STF adotado no RE 680.371 $\mathrm{AgR}^{28}$ e, ao mesmo tempo, superou o enunciado n. 418 da jurisprudência dominante do STJ, que afirma exatamente o contrário. ${ }^{29}$ Essa também foi a conclusão do enunciado n. 23, do FPPC, em que se afirma que "Fica superado o enunciado 418 da súmula do STJ após a entrada em vigor do CPC ("É inadmissível o recurso especial interposto antes da publicação do acórdão dos embargos de declaração, sem posterior ratificação")". ${ }^{30}$ Afinal, se o posicionamento do STJ tem por base a interpretação da legislação infraconstitucional e ela é alterada para afirmar exatamente o contrário do que aponta o enunciado n. 418 da Jurisprudência dominante do STJ, impõe-se a sua superação. ${ }^{31}$ Isso acabou acontecendo na sessão de 1 de julho de 2016 da Corte Especial do STJ, que cancelou a súmula n. 418, com a consequente edição da súmula n. 579, segundo a qual "Não é necessário ratificar o recurso especial interposto na pendência do julgamento dos embargos de declaração, quando inalterado o resultado anterior".

28 STF, $1^{\mathrm{a}}$ T., RE 680.371 AgR, Rel. Min. Dias Toffoli, Rel. p/ Acórdão: Min. Marco Aurélio, j. 11/06/2013, DJe $16 / 09 / 2013$.

29 S. 418: É inadmissível o recurso especial interposto antes da publicação do acórdão dos embargos de declaração, sem posterior ratificação".

30 No mesmo sentido: MAZZEI, Rodrigo. Comentários ao art. 1.024. DIDIER JR., Fredie; TALAMINI, Eduardo; WAMBIER, Teresa Arruda Alvim; DANTAS, Bruno. Breves comentários ao Novo Código de Processo Civil. São Paulo: RT, 2015, p. 2281-2282; NEVES, Daniel Amorim Assumpção. Novo Código de Processo Civil - Lei 13.105/2015. São Paulo: Método, 2015, p. 571 .

31 Sobre o diálogo entre os precedentes e as alterações dos textos normativos: PEIXOTO, Ravi. Superação do precedente e segurança jurídica. $2^{\mathrm{a}}$ ed. Salvador: Juspodivm, 2016, p. 158-160, 184. Ver ainda, com longo aprofundamento sobre o tema, a partir da teoria dos diálogos constitucionais, embora o foco seja na jurisdição constitucional: BRANDÃO, Rodrigo. Supremacia judicial versus diálogos constitucionais: a quem cabe a última palavra sobre a Constituição. $2^{2}$ ed. Rio de Janeiro: Lumen Juris, 2017. 
A súmula n. 418 do STJ sempre foi criticada pela doutrina por ser um infeliz exemplo de jurisprudência defensiva, ${ }^{32}$ pois não fazia sentido exigir que o embargado que interpôs o recurso anteriormente fosse obrigado a ratificá-lo mesmo que não houvesse qualquer alteração da decisão. Ora, se a parte já manifestou o interesse em recorrer e o fez de forma tempestiva, qual seria a necessidade de ratificar o recurso? Nenhuma. O interesse, por óbvio, permanece intacto.

De fato, o problema ocorreria apenas quando houvesse alteração relevante do julgado. O CPC optou por permitir que a parte alterasse o recurso, enquanto que o STF, no precedente citado, consta obiter dictum do Ministro Marco Aurélio de que, em tal hipótese, o recurso estaria prejudicado e, aparentemente, a parte deveria interpor novo recurso. A solução do CPC/2015 parece mais adequada. O que parece ocorrer é que, havendo alteração significativa da decisão, a parte poderá alterar o seu recurso, mas, caso não o faça, este não será considerado prejudicado. Continuará a ser processado e eventualmente julgado. Caberá à parte arcar com os riscos da não alteração do recurso.

Uma última advertência: o $\$ 5^{\text {o }}$ parece indicar que apenas poderá haver aditamento do recurso quando haja modificação na conclusão da decisão, mas não menciona alteração relevante na fundamentação da decisão. Parece ser possível, no entanto, ampliar o direito da parte de aditar o recurso para outras hipóteses de provimento dos embargos de declaração, pois é viável que a alteração da fundamentação implique na necessária mudança do recurso cabível. Pode haver o prequestionamento de outro artigo da legislação infraconstitucional ou mesmo o prequestionamento de texto normativo constitucional e passar a ser cabível o recurso extraordinário da referida decisão.

Assim, o que se propõe é o seguinte: rejeitados os embargos, o recurso será simplesmente processado e julgado. Providos os embargos, deve ser concedido à parte o direito ao aditamento, até porque a ela incumbe analisar se foi ou não relevante a alteração, seja da fundamentação ou da conclusão do julgado, de forma a gerar uma necessária alteração nas razões do seu recurso ou mesmo implicar na interposição de outro recurso. E, por óbvio, essas mudanças nem sempre são provocadas por alterações apenas na conclusão do julgado. Portanto, a "modificação da decisão embargada" a que faz referência o $\$ 4^{\circ}$ do art. 1.024 abrange mais do que a "conclusão do julgamento anterior" a que faz referência o $\$ 5^{\circ}$ do mesmo artigo, de forma a permitir ou não a alteração do recurso. O que importa é que o direito a alteração esteja sempre limitado ao que foi alterado pela decisão embargada, independentemente de onde esteja a mudança.

\section{Sobre a aplicação analógica do direito ao aditamento para os embargos de divergência}

Ao contrário da situação existente nos embargos de declaração, os embargos de divergência não possuem qualquer previsão de direito ao aditamento do recurso, seja quando há alteração da conclusão, em que há previsão expressa para o primeiro, ou nas situações em que há alteração da fundamentação, como foi proposto por este texto.

Podem ocorrer algumas situações em que haja alteração na decisão e que reflita no cabimento do recurso extraordinário já interposto. Afinal, se existem dois capítulos relativos a matéria constitucional na mesma decisão é possível que sobre um deles haja interesse para a interposição do recurso extraordinário e, sobre o outro, sejam cabíveis os embargos de divergência. Caso o capítulo relativo aos embargos de divergência viesse a ter sua conclusão ou fundamentação alterada, mesmo que rejeitado, pode surgir o interesse da parte em alterar o seu recurso. Entretanto, o CPC não cogita de tais hipóteses, tratando apenas da situação em que os embargos de divergência não são providos ou não alterem a conclusão do julgado anterior, caso em que o recurso não irá necessitar de ratificação (art. 1.044, $2^{\circ}$ ).

Cabe, inclusive, uma breve digressão ao que parece ter sido uma desatenção do legislador. Isso porque, não parece possível que o recurso de embargos de divergência seja provido e não altere a conclusão do

32 V.porexemplo, textoescritoem coautoriacom FredieDidierJr.eLeonardoCarneirodaCunhaem relaçãoaoCPC/1973: Súmula do STJ, N.418. Recente precedente do STF em sentido diverso. Disponível em: https://www.academia.edu/4111059/ Ravi_Peixoto_-_Leonardo_Carneiro_da_Cunha_-_Fredie_Didier_-_Opini\%C3\%A3o_12_S\%C3\%BAmula_do_ STJ_N.418._Recente_precedente_do_STF_em_sentido_diverso. Acesso às 23h, do dia 02 de maio de 2019. 
julgado anterior, como cogita o texto normativo. Afinal, se o recurso não é provido, a única hipótese diversa disso é o seu provimento. Esse erro lógico provavelmente deriva do fato de que é nítido que o legislador copiou, sem a devida atenção, o art. 1.024, §5º , do CPC, destinado aos embargos de declaração e o colocou para os embargos de divergência. Veja-se o texto relativo aos embargos de declaração e aos embargos de divergência de forma comparada, com as diferenças apontadas em negrito:

Art. 1.024. (...) $5^{\circ}$ Se os embargos de declaração forem rejeitados ou não alterarem a conclusão do julgamento anterior, o recurso interposto pela outra parte antes da publicação do julgamento dos embargos de declaração será processado e julgado independentemente de ratificação.
Art. 1.044. (...) \$2 Se os embargos de divergência forem desprovidos ou não alterarem a conclusão do julgamento anterior, o recurso extraordinário interposto pela outra parte antes da publicação do julgamento dos embargos de divergência será processado e julgado independentemente de ratificação.

O problema dessa aparente cópia do tratamento de um recurso para outro foi a falta de percepção de que eles funcionam de forma diferente, pois, no caso dos embargos de declaração, faz sentido a previsão da possibilidade de não provimento do recurso ou não alteração da conclusão do julgamento anterior, pois, nesse caso, o provimento dos embargos pode gerar alteração apenas da fundamentação, no caso da omissão na apreciação de um fundamento. Tal possibilidade não existe para os embargos de divergência, que, tal como a grande maioria dos recursos, caso seja conhecido, apenas pode ser improvido ou provido com alteração da conclusão. Por isso, a parte em que se faz referência aos embargos de divergência sem alteração da conclusão do julgamento anterior não faz sentido, pois está logicamente inserida na primeira parte do texto normativo, ou seja, a que faz referência ao seu desprovimento.

Voltando à discussão da situação lacunosa, parece haver aqui uma possibilidade de aplicação analógica da previsão constante para os embargos de declaração. Isso porque são obedecidos os três princípios básicos para a utilização da analogia mencionados por Langenbucher e que parecem ser um bom critério para o uso da técnica também no Brasil: ${ }^{33}$

a) há uma nítida omissão, eis que situações em que a decisão do STJ é alterada, com reflexos no cabimento do recurso extraordinário não são tratadas, seja para impedir ou permitir a modificação do extraordinário já interposto;

b) não há qualquer vedação constitucional a essa analogia; e

c) tem-se similaridades significantes entre a situação existente nos embargos de divergência e o objetivo da permissão do aditamento ao recurso no caso dos embargos de declaração. No caso dos embargos de declaração, como o recurso é facultativo, devendo ser oposto antes da utilização de outros recursos, ele pode levar a uma alteração na fundamentação ou na conclusão que gere uma necessidade de alteração no recurso já interposto. É preciso lembrar que a outra parte interpôs o recurso corretamente, dentro do prazo, mas outrem opôs embargos de declaração, gerando a interrupção do prazo e criando a possibilidade de alteração da decisão. A ideia do aditamento é a de proteger aquele que se adiantou na interposição do recurso, mas que foi prejudicado pela oposição posterior dos embargos de declaração por outrem.

A mesma situação está presente nos embargos de divergência, em que a parte se adianta, no seu prazo legal, para a interposição do recurso extraordinário, mas, como outrem opta por interpor os embargos de divergência, o cabimento do extraordinário pode ser afetado pela decisão nos embargos de divergência. Veja-se que, no caso dos embargos de divergência, a situação ainda tem maior necessidade de regulação porque o prazo dos embargos de declaração é de 5 dias e o dos demais recursos é de 15 dias, ou seja, em tese, a outra parte poderia esperar acabar o prazo dos embargos de declaração, para depois, interpor o recurso adequado para atacar a decisão. Isso não ocorre no caso dos embargos de divergência, que também tem o prazo de 15 dias. Nessa situação, caso a parte com interesse de recorrer extraordinariamente viesse a esperar a outra interpor ou não o recurso de embargos de divergência, poderia acabar sem prazo para o seu recurso extraordinário. 
Nas duas situações, tem-se um recurso que pode alterar uma decisão que já foi alvo de recurso corretamente interposto pela outra parte, não sendo adequado que possuam regulação diversa. Se a analogia tem por base o princípio geral de que deve se dar tratamento igual a casos semelhantes, ${ }^{34} \mathrm{a}$ aplicação analógica da complementação ou alteração recursais existente nos embargos de declaração aos embargos de divergência deve ser admitida, devido às semelhanças relevantes entre as duas situações. Portanto, parece imprescindível a aplicação analógica do direito ao aditamento dos embargos de declaração para o caso dos embargos de divergência. ${ }^{35}$

É preciso, então, verificar a forma de aplicação desse direito ao aditamento constante dos embargos de declaração para os embargos de divergência.

Inicialmente, é de se utilizar o mesmo raciocínio que foi desenvolvido para os embargos de declaração: o direito ao aditamento deve ser garantido havendo ou não alteração do dispositivo. Isso porque, como o recurso extraordinário tem uma forte conexão com a justificação da decisão, a inserção ou a retirada de um fundamento constitucional pode implicar na completa alteração dos fundamentos para esse recurso.

Uma diferença primordial entre os dois recursos é a seguinte: o que se cogitou foi que, nos embargos de declaração, o seu provimento pode não gerar alteração do dispositivo, mas apenas da fundamentação. Essa possibilidade não existe no caso dos embargos divergentes. Se ele for provido, há alteração no dispositivo (o que não parece ter sido percebido pelo legislador, no art. 1.044, $\$ 2^{\circ}$ ). No entanto, pode haver o desprovimento, mas com alteração da fundamentação. É possível, por exemplo, haver inserção de novo fundamento constitucional e que haja nítido interesse recursal de alterar o recurso extraordinário.

Portanto, a aplicação analógica do direito ao aditamento do recurso pela alteração tão somente da fundamentação, no caso dos embargos de divergência, ao contrário do que ocorre nos embargos de declaração, ocorre no caso do desprovimento com alteração da justificação.

Portanto, é possível considerar o seguinte: por meio da aplicação analógica do art. 1.024, §4º do CPC aos embargos infringentes, havendo alteração do dispositivo ou da justificação, a parte que já tiver interposto o recurso extraordinário contra a decisão originária poderá complementar ou alterar suas razões recursais, nos exatos limites da modificação, no prazo de 15 dias, contado da intimação da decisão dos embargos de divergência.

Um ponto que é interessante destacar é que, mesmo que haja a alteração do dispositivo da decisão, o que se tem é um direito do recorrente de complementar ou alterar as razões do seu recurso. Não se trata de uma obrigatoriedade, como uma espécie de ratificação, sob pena de se considerar falta de interesse recursal automática. Não havendo essa alteração do recurso, é no juízo de admissibilidade que se verificará se o recurso foi prejudicado. ${ }^{36}$

\section{Conclusão}

Os embargos de divergência são uma espécie recursal que ganha nova importância no CPC/2015, eis que se trata de um relevante mecanismo para a uniformização da jurisprudência interna dos tribunais

34 FERRAZ JR., Tercio Sampaio. Introdução ao estudo do direito. $5^{\underline{a}}$ ed. São Paulo: Atlas, 2007, p. 316.

35 Também admitindo essa aplicação analógica: CÂMARA, Alexandre Freitas. O novo processo civil brasileiro. São Paulo: Atlas, 2015, p. 559. Admitindo a possibilidade de complementação, mas sem mencionar a aplicação analógica da regulação dos embargos de declaração: ASSIS, Araken de. Manual dos recursos. 8ª ed. São Paulo: RT, 2017, versão eletrônica, tópico 98.1, 100.3. Pedro Miranda de Oliveira parece não cogitar de eventual interesse na complementação ou alteração do recurso, ao afirmar que: "se os embargos de divergência forem providos deve a parte tomar alguma atitude após a publicação do acórdão? Tem-se que não! Apesar da literalidade do dispositivo, o CPC/2015 afasta qualquer exigência de reiteração do RE, seja qual o for o resultado do julgamento dos embargos de divergência. Até porque são capítulos distintos, autônomos, com objetos diferentes (questão infraconstitucional e questão constitucional).” (OLIVEIRA, Pedro Miranda. Novíssimo sistema recursal conforme o CPC/2015... cit., p. 343). Esse posicionamento parece ignorar hipóteses, já mencionadas nesse texto, em que a decisão dos embargos de divergência pode gerar interesse, no recorrente do extraordinário, em complementar ou alterar as suas razões recursais.

36 CÂMARA, Alexandre Freitas. O novo processo civil brasileiro... cit., p. 559. 
superiores. E a uniformização é um elemento básico para que os precedentes possam servir como pauta de conduta para os jurisdicionados. Afinal, a uniformidade é um dever básico dos tribunais mencionado expressamente pelo art. 926 do CPC, sem o qual os demais deveres (estabilidade, integridade e coerência) tornam-se inatingíveis.

Houve também várias alterações quanto ao cabimento dessa espécie recursal perante dos tribunais superiores, com maior detalhamento das suas hipóteses e requisitos, bem como do próprio procedimento do recurso. No que se refere aos objetivos deste texto, foi tratada a hipótese em que seriam cabíveis embargos de divergência e recurso extraordinário perante um mesmo acórdão do STJ e os casos em que o recurso extraordinário é interposto antes da publicação do acórdão que julgou os embargos de divergência.

No entanto, mesmo assim, houve uma omissão, eis que apenas se cogita da não alteração da decisão e a manutenção do interesse recursal, em que é desnecessária a ratificação (art. 1.044, §2º CPC). Não houve qualquer menção ao procedimento no caso de haver alguma espécie de alteração da decisão como consequência do julgamento dos embargos infringentes.

O objetivo deste texto foi o de sanar essa lacuna por meio da proposta da aplicação analógica do art. 1024, $\$ 4^{\circ}$, do CPC, que trata do direito ao aditamento decorrente de alteração na decisão originária provocada pela oposição de embargos de declaração. A proposta é a de que, no caso dos embargos de divergência, havendo alteração do dispositivo ou da justificação (que pode ocorrer no desprovimento do recurso), a parte que já tiver interposto o recurso extraordinário contra a decisão originária poderá complementar ou alterar suas razões recursais, nos exatos limites da modificação, no prazo de 15 dias, contado da intimação da decisão dos embargos de divergência. Caso não o faça, ficará sujeita à constatação de que o seu recurso foi prejudicado, mas, de toda forma, será desnecessária a ratificação.

\section{Referências}

ALVIM, Teresa Arruda Alvim. Comentários ao art. 1.043. STRECK, Lênio Luiz; NUNES, Dierle; CUNHA, Leonardo Carneiro; FREIRE, Alexandre (Coords.). Comentários ao Código de Processo Civil. São Paulo: Saraiva, 2016.

ALVIM, Teresa Arruda; DANTAS, Bruno. Recurso especial, recurso extraordinário e a nova função dos tribunais superiores no direito brasileiro. $3^{\mathrm{a}}$ ed. São Paulo: RT, 2016.

BRANDÃO, Rodrigo. Supremacia judicial versus diálogos constitucionais: a quem cabe a última palavra sobre a Constituição. 2a ed. Rio de Janeiro: Lumen Juris, 2017.

ASSIS, Araken de. Manual dos recursos. 7ํㅡㄹ. edão Paulo: RT, 2015.

Manual dos recursos. $8^{\mathrm{a}}$ ed. São Paulo: RT, 2017, versão eletrônica.

CÂMARA, Alexandre Freitas. O novo processo civil brasileiro. São Paulo: Atlas, 2015.

CUNHA, Leonardo Carneiro da; DIDIER JR., Fredie. Curso de direito processual civil. 13ª ed. Salvador: Juspodivm, 2016, v. 3.

FERRAZ JR., Tercio Sampaio. Introdução ao estudo do direito. $5^{\mathrm{a}}$ ed. São Paulo: Atlas, 2007.

FREIRE, Rodrigo da Cunha Lima. Embargos de divergência em recurso especial e em recurso extraordinário. No prelo.

GRAU, Eros Roberto. O direito posto e o direito pressuposto. 7a ed. São Paulo: Malheiros, 2008.

Por que tenho medo dos juízes (a interpretação/aplicação do direito e os princípios). São Paulo: Malheiros, 2014.

JORGE, Flávio CHeim. Teoria geral dos recursos cíveis. 7ª ed. São Paulo: RT, 2015.

LANGENBUCHER, Katja. Argument by analogy in European law. Cambridge Law Journal, v. 57, nov.1998. 
LEMOS, Vinicius. Recursos e processos nos tribunais no novo CPC. 2aㅡ ed. São Paulo: Lexia, 2016.

MACEDO, Lucas Buril de. Precedentes judiciais e o direito processual civil. 2ª ed. Salvador: Juspodivm, 2017.

MANCUSO, Rodolfo Camargo de. Divergência jurisprudencial e súmula vinculante. $4^{\mathrm{a}}$ ed. São Paulo: RT, 2010 .

MARINONI, Luiz Guilherme. O STJ enquanto Corte de precedentes. 2a ed. São Paulo: RT, 2014.

MAZZEI, Rodrigo. Comentários ao art. 1.024. DIDIER JR., Fredie; TALAMINI, Eduardo; WAMBIER, Teresa Arruda Alvim; DANTAS, Bruno. Breves comentários ao Novo Código de Processo Civil. São Paulo: RT, 2015.

MOREIRA, José Carlos Barbosa. Comentários ao código de processo civil. 14ํㅡㄹ ed. Rio de Janeiro: Forense, 2008, v. V.

Efetividade e técnica do processo. BARBOSA MOREIRA, José Carlos (coord). Revista Forense - comemorativa 100 anos. Rio de Janeiro: Forense, 2006, t. V.

O juízo de admissibilidade no sistema dos recursos civis. Revista de Direito da Procuradoria Geral do Rio de Janeiro. Rio de Janeiro, v. 17, 1976.

Questões de técnica de julgamentos nos tribunais. Temas de direito processual: nona série. São Paulo: Saraiva, 2007.

NEVES, Daniel Amorim Assumpção. Novo Código de Processo Civil - Lei 13.105/2015. São Paulo: Método, 2015.

OLIVEIRA, Pedro Miranda. Novíssimo sistema recursal conforme o CPC/2015. 3aㅡ ed. Florianópolis: Empório do Direito, 2017.

PEIXOTO, Ravi. Superação do precedente e segurança jurídica. 2ª ed. Salvador: Juspodivm, 2016.

PEIXOTO, Ravi; SILVEIRA, Marcelo Pichioli da. Ação Rescisória e competência: novos e velhos problemas. Revista Brasileira de Direito Processual - RBDPro, Belo Horizonte: Fórum, n. 96, out./dez.2016.

PEIXOTO, Ravi; DIDIER JR., Fredie; CUNHA, Leonardo Carneiro da. Súmula do STJ, N.418. Recente precedente do STF em sentido diverso. Disponível em: https://www.academia.edu/4111059/Ravi_ Peixoto_-_Leonardo_Carneiro_da_Cunha_-_Fredie_Didier_-_Opini\%C3\%A3o_12_S\%C3\%BAmula_ do_STJ_N.418._Recente_precedente_do_STF_em_sentido_diverso. Acesso às 23h, do dia 02 de maio de 2017 .

PEREIRA, Milton Luiz. Embargos de divergência contra decisão lavrada por relator. Revista dos Tribunais. São Paulo: RT, v. 778, ago.-2000.

RODRIGUES, Luiza Silva. Embargos de divergência: o cumprimento da função precípua dos tribunais superiores. Dissertação de Mestrado. Santa Catarina: UFSC, 2017.

SOUZA, Bernardo Pimentel. Introdução aos recursos cíveis e à ação rescisória. 10ª ed. São Paulo: Saraiva, 2014.

ZAVASCKI, Teori Albino. Jurisdição constitucional do Superior Tribunal de Justiça. Revista de Processo. São Paulo: RT, n. 212, set.-2012, versão eletrônica. 